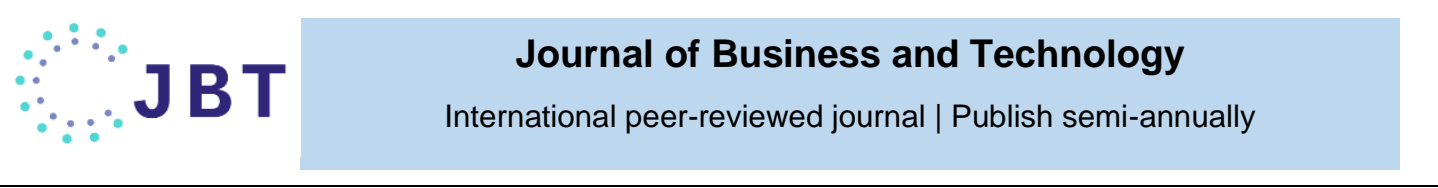

\section{Trust Repair Efforts and Repurchase Intention after Negative Publicity of Milk Powder in Sri Lanka}

\author{
Thilini T. Ranasinghe ${ }^{1}$ and Mohamed M. Shamil ${ }^{2^{*}}$ \\ ${ }^{1}$ Bachelor of Commerce Graduate of Department of Commerce and Financial Management. \\ 2 Department of Commerce and Financial Management, University of Kelaniya. \\ * Corresponding Author: shamil@kln.ac.lk
}

\begin{abstract}
This paper aimed to examine the impact of trust repair efforts on consumers repurchase intention of milk powder products affected by negative publicity in Sri Lanka. Consumer response to business entity's effort to mitigate negative information are understudied in developing economies including Sri Lanka. A quantitative survey design was opted for this study. Data was collected from 140 consumers residing in the western province of Sri Lanka employing a questionnaire during the pandemic. The proposed hypotheses were analyzed using an OLS regression. Our findings revealed that functional repair efforts, affective repair efforts, and informational repair efforts have a significant and positive impact on repurchase intention. Among the three trust repair efforts, informational repair efforts were found to be the most important trust repair efforts that influence the repurchase intention. Based on the findings, milk powder producers in Sri Lanka should pay attention to strengthening ties with the consumers and consider trust repairing efforts to negate negative campaigns. The main limitation of the study is that data collection had to be limited among the urban consumers and collecting data randomly was challenging due to the pandemic. Nevertheless, our study contributes to the growing body of literature on trust repairing and trust theory from an under-explored economic and socio-cultural context.
\end{abstract}

Keywords: Affective repair, Functional repair, Informational repair, Trust theory

JEL Codes: M39

\section{INTRODUCTION}

Bad news can cause considerable damage to an organization. Takata corporation and Boeing are some of the recent examples where companies had to go bankrupt, or their operation got disrupted due to equipment failure and software glitch. Boeing incurred losses for the first time in two decades after the two deadly 737 Max crashes ("Boeing puts" 2020). Likewise, Volkswagen's car sales fell 5.3\% in October 2015 after the company admitted to rigging emission tests (Kottasova, 2015). In the cases of Boeing and VW, CEOs had to step down as the incidents had a severe negative impact on the companies. In Japan, the CEO is expected to stand down in the aftermath of a crisis. In the past, adverse effects of business activities were treated as minor externalities; however, today, such crisis is not ignored and receive significant attention (Mitroff, Shrivastava, \& Udwadia, 1987).

\section{Negative publicity}

Negative information or publicity is a form of a problem or crisis that organizations face. Negative publicity is generally viewed as a management problem and can hurt the success of a business (Henthorne \& Henthorne 1994). Negative campaigns have been aggravated by the increasing use of social media and the 
ISSN 2738-2028 (Online) | Vol. 5 | No. 2 | 2021 July

internet. The risk of businesses exposed to the negative campaign has heightened as unsubstantiated information is circulated using tech-based media platforms. It has been claimed that consumer decisions are more likely to be affected by negative information than positive information (Eagly \& Chaiken 1993), and generally information processing is steered by the cognitive economy principle (Ahluwalia \& Gurhan-Canli 2000).

Prior studies have shown that negative information lowered the consumption of foods associated with negative publicity (see Brown, 1969; Swartz \& Strand, 1981; and Youn, Lim \& Jin 2012). Investigating the sales loss in the aftermath of milk contamination in Hawaii, Smith, van Ravenswaay and Thompson (1988) found that the impact of negative media coverage superseded the positive coverage to deter milk purchases. Authors also claimed that government assurance of food safety and statements from the producers were futile in restoring consumer trust (Smith et al., 1988).

How do companies strategize against adverse publicity, and how do consumers evaluate corporations reaction to negative publicity is understudied claims Vyravene and Rabbane (2016). Yu, Liu, Lee, \& Soutar (2018) reports that most negative publicity research have concentrated on Western consumers, and there has been less attempt to understand how consumers in other cultures respond to such information. Some past studies have revealed that cultural differences may influence consumers to blame the brands for causing negative publicity and purchase decisions (see Laufer, Gillespie, McBrider, \& Gonzalez, 2005; and Turnbull, Leek \& Ying 2000).

\section{Research context}

This paper focuses on the powdered milk products in Sri Lanka. Annual per capita milk consumption in Sri Lanka in 1983 was around $13 \mathrm{Kg}$, and it was around $36 \mathrm{Kg}$ in 1997 (Ibrahim, Staal, Daniel, \& Thorpe, 1999). According to Vidanarachchi et al. (2019) Sri Lanka's annual per capita milk consumption in 2018 was approximately $35 \mathrm{Kg}$. While Sri Lanka's annual per capita milk consumption is below India and Pakistan, it is higher than some developing economies. Domestic milk production in Sri Lanka fulfils only $38 \%$ of the national requirement (Central Bank, 2019). Hence, milk products mainly in the form of powdered milk are imported to Sri Lanka. As a result, per capita powdered milk consumption in Sri Lanka is higher than liquid milk consumption. It has been claimed that milk powder import amounts to US \$300 million per annum (Lugoda, 2020). Milk production in Sri Lanka has increased over the years with the intervention of government policies and initiatives. In the past decade, a debate has emerged within the Sri Lankan community 'whether consuming milk powder is unhealthy?'.

The first blow to the milk powder importers in Sri Lanka was the Ministry of Technology and Research revelation that a harmful substance identified as Dicyandiamide (DCD) had been found in four imported milk powder brands in 2013 ("Harmful chemical" 2013). In 2014, a leading importer of milk powder was suspended from distributing and selling milk products after some consumers claim to have fallen ill after consuming the company's milk powder (Aneez \& Sirilal, 2014). The suspension was lifted later. The second blow occurred when a Deputy Minister claimed that a harmful substance are included in imported milk powder in the parliament of Sri Lanka in 2019 (Siriwardena \& Perera, 2019). The discourse about the negatives of milk powder consumption involving medical professionals, parliamentarians, educators, and consumers in Sri Lankan society continues to persist and evolve after the above revelation. On $20^{\text {th }}$ January 2020, a program was launched by the Government Medical Officers' Association (GMOA) and the Ministry of Health to raise awareness among the general public about the health risks of imported milk powder consumption at the National Hospital of Sri Lanka (NHSL) (Gunatilleke, 2020).

The GMOA has been an outright critique of milk powder consumption and claims it may cause many non-communicable diseases (see Vishwa Karma, 2019; and Government Medical Officers' Association, 2019). However, milk powder importers in Sri Lanka stressed that the claim milk powder consumption is unhealthy is unsubstantiated 
ISSN 2738-2028 (Online) | Vol. 5 | No. 2 | 2021 July

and whether milk powder consumption causes diseases is not based on scientific justification ("Companies say" 2020). Nevertheless, the Consumer Affairs Authority (CAA) classified imported milk powder as high-risk food items citing several reasons (Dissanayake, 2019). This is even though an interim report of the CAA revealed that there was no adulteration in milk powder imported to Sri Lanka (“Companies say" 2020).

In response to the above developments, milk powder importers and producers of Sri Lanka have taken various steps to mitigate the negative criticism towards the industry. These include investing in technologies to detect foreign matter in its milk powder plants, milk preservation and traceability, increasing sourcing from local suppliers, highlighting their SLS acceptance, conducting advisory workshops partnering with officials, and engaging with communities to uplift their livelihoods.

Studies that have attempted to explore the effect of negative publicity consumer purchase intentions, consumer trust or and trust repair are few in the context of Sri Lanka. Hence, this paper attempts to examine whether consumers are willing to repurchase milk powder products affected by negative publicity after considering the trust repairing efforts by the producers.

This paper is organized as follows. The following section focuses on the trust repairing literature, relevant theories, and the hypotheses. Subsequent sections detail the methods applied in this study followed by the findings of the study. Final section concludes the study by linking the findings to previous studies and highlighting the implications.

\section{RELEVANT LITERATURE, THEORY, AND HYPOTHESES}

\section{Consumer trust repair}

A company's response to a negative campaign lies between two extremes. At one extreme is stonewalling, which is to deny responsibility or absence of any form of measures or communications, and at the other extreme is an apology to the consumers or victims (Dawar \& Pillutla, 2000). There may lie many ambiguous efforts from the violator between these extremes. Trust repair is one such mechanism pursued by the violating party in the aftermath of an adverse event. Bozic (2017, p. 535) defines trust repair or trust restoration as the "improvement in a trustor's trust after a trust violation damaged it." Trust repair has been generally looked upon as a dyadic relationship between the victim (trustor) and violator (trustee) (Schweitzer, Hershey, \& Bradlow, 2006). The interest of this paper lies in the dyadic relationship between consumer and the companies producing and distributing milk powder affected by the negative publicity.

Chen, Wu, and Chang (2013) claim that trust repairing plays a vital role in determining customer feelings in the event of a trust violation. Kim, Ferrin, Cooper, \& Dirks (2004) claim that trust repairing is complex and may require different strategies. Prior studies reveal that trust repair may encompass functional repair efforts, affective repair efforts and informational repair efforts (Cao, Shi, \& Yin, 2014; Chen et al., 2013). Economic or monetary compensation for the consumers affected by the trust violation falls within the scope of functional repair efforts (Xie \& Peng, 2009). An earnest apology from the trust violator to the consumers and public is identified as an affective repair effort (Kim et al., 2004; Xie \& Peng 2009). Using channels of communication to disseminate up-to-date information and to demonstrate steps taken to mitigate future incidents is regarded as informational repair efforts (Chen et al., 2013).

\section{Repurchase intention}

Repurchase intention is the decision of an individual to buy a designated product or service again (Hellier, Geursen, Carr, \& Rickard, 2003). Buyers usually would have the first-hand experience with sellers and repurchase is a situation where the buyer use previous experiences as a source of making purchase decisions (Sullivan \& Kim, 2018). Some scholars have pointed out that negative publicity adversely affects repurchase intention ( $\mathrm{Yu}$ et al., 2018). In the case of a product or a service being perceived to be low in value because of low quality or high price, the intention to purchase is expected to be low 
(Sullivan \& Kim, 2018), and negative publicity can further damage the overall perceived value of the product. Managers may attempt to use public relations to convince consumers of the product value in the aftermath of negative information (Yu et al., 2018).

\section{Theoretical background A theory of consumer trust}

Trust theory (see Isaeva, Gruenewald, \& Saunders 2020) provides a foundation for enabling customer trust for organizations. Isaeva et al. (2020) propose three recommendations on how service organizations can work towards enabling customer trust. Their conceptualization of trust theory can be extended to organizations in other industries. First, the authors propose that organizations and their representatives should take a proactive approach to customer trust. This shall include selecting and training employees to demonstrate trustworthy behaviour and institutionalizing trustworthy behaviour using formal and informal controls (Isaeva et al., 2020). Second, to avert trust violations in the early stages of the relationships and establish plans to respond to any incidence of violations. Third, to initiate trust repair. Prior studies have established that trust has three components, namely cognitive, affective, and behavioural. The cognitive element of trust deals with beliefs and expectations, the affective element of trust deals with emotional connectivity, and the behavioural aspect of trust is concerned with the actual behaviour of the trustor (Lewicki \& Briensfield, 2017). Thus, the three main domains of the trust theory based on the work of Isaeva et al. (2020) can be further strengthened by absorbing a comprehensive understanding of the concept of trust.

\section{Hypotheses development}

Functional repair efforts are centered around economic compensation (Cao et al., 2014). It is a common act for businesses to provide some financial compensation to resolve a negative event or fault experienced by a customer in obtaining a product or services from a business (Xie \& Peng 2009). Initiating functional repair efforts by a company experiencing negative publicity may have a positive or negative or impact on customers' repurchase intention. Cao et al. (2014) revealed that functional repair efforts showed no significant influence on repurchase intention after negative publicity in the context of Chinese dairy products. In contrast, Chen et al. (2013) revealed that functional repair remedies cause positive moods among consumers in an e-commerce context. Moreover, Xie and Peng (2009) have shown that functional repair reveals a company's intention to look after the well-being and interest of its consumers. Accordingly, the following hypothesis is suggested.

$H_{1}$ : Functional repair efforts significantly influence the repurchase intention of milk powder post negative publicity.

Typically, affective repair efforts involve apologizing to the victims and public and expressing regret (Kim et al. 2004). Responding to negative publicity or resolving customers' criticisms helps to improve customer satisfaction with the perception of justice and rebuild trust in the organization (Brown, Chandrashekaran, \& Tax, 1998). Extant studies have shown that if a customer receives an honest apology after an unhappy shopping experience, the customer perceives interactional justice (Smith, Bolton, \& Wagner, 1999). Cao et al. (2014) and Chen et al. (2013) have explored affective repair efforts in their studies and found they positively affect repurchase intention. It can be assumed that repairing the customer's emotional distress seems to be particularly important. Hence, the following hypothesis is proposed.

$\mathrm{H}_{2}$ : Affective repair efforts significantly influence the repurchase intention of milk powder post negative publicity.

Informational repair efforts typically entail appropriate communication such as showing evidence, clarifying facts, and divulging upto-date news over the crisis handling stage (Xie \& Peng, 2009). Research findings of Yu et al. (2018) have revealed that negative information may impact customer attitudes and repurchase intention ( $\mathrm{Yu}$ et al., 2018). Alternatively, studies have shown that information repair efforts may effectively influence customers' positive mood and 
repurchase intention (Cao et al., 2014; Chen et al., 2013). Correspondingly, the following hypothesis is proposed.

$H_{3}$ : Informational repair efforts significantly influence the repurchase intention of milk powder post negative publicity.

\section{METHODOLOGY}

\section{Sample and data collection}

Milk powder consumers in the Western province of Sri Lanka is the population of this study. According to the Central Bank Annual Report (2019), Western Province has the highest household expenditure share as a percentage for milk and milk product category. It was intended to collect at least 200 responses from Milk powder consumers. Data collection became a daunting task amidst the nCovid-19 pandemic. Leading supermarket chain outlets in the Western province were visited, and approval was obtained from the respective managers to collect data for the questionnaire. Due to the pandemic and organization policies, data collection was not permitted inside the outlets. However, the managers did permit to collect data from the outside of the outlets. Accordingly, several outlets belonging to the three districts in the Western province was visited on Monday, Wednesday, and Friday from 5.00 p.m. to 6.30 p.m. Every third customer exiting the outlet after making purchases was approached and asked 'whether they are willing to participate in the survey' and 'whether they had purchased Milk powder'. 140 questionnaires were collected after two months of effort.

\section{Questionnaire development}

The questionnaire was designed to include two sections. The first section included questions about the responding consumer's profile. The second section of the questionnaire included questions to measure the proposed variables. The predictor variables of this study are functional repair efforts (3 items), affective repair efforts (4 items) and informational repair efforts (5 items). These variables were measured on a 7point Likert scale ranging from 1 (strongly disagree) to 7 (strongly agree). Repurchase intention is the outcome variable and was measured using 3 items on a Likert scale ranging from strongly disagree (1) to strongly agree (9). See the annexure for the questionnaire items and the sources.

\section{Analysis method}

This paper applies descriptive statistics, correlation analysis and multiple linear regression (MLR) to analyze the collected data. MLR shall be executed using the ordinary least square (OLS) estimation technique. Statistical Package for Social Science (SPSS) version 25 was used for data analysis.

\section{FINDINGS}

\section{Sample adequacy}

As mentioned before, the data collection was undertaken amidst the pandemic. Although the intention was to collect more than 200 responses, 150 questionnaires were collected after two months of effort. However, 10 questionnaires had to be removed due to incompleteness and missing data. Thus, 140 complete and usable questionnaires were available for the analysis. Although it may be argued that the sample size may be small in the case of consumer behaviour studies, approaching customers in the context of a pandemic to obtain their consent and collect data was an arduous task. As for the MLR there are more than 9 observations per question item, and there are 35 observations per variable. Furthermore, this study only intends to examine the direct impact of the predictor variables. Hence, it can be deemed that the response rate is adequate to perform the analysis and test the proposed hypotheses.

\section{Respondent profile}

Table 1 provides background details of the consumers who responded to the survey. As depicted in the Table, the majority of the respondents were female. Details of the marital status of the respondents suggest most of the respondents were married. Most of the respondents were from Colombo and Kaluthara districts. Gampaha district had the lowest participation in the survey. Education qualifications of the respondents indicate that many of the respondents had passed the 
ISSN 2738-2028 (Online) | Vol. 5 | No. 2 | 2021 July

G.C.E. (A/L) examination in Sri Lanka, and $47.1 \%$ of the respondents had obtained a bachelor degree or professional qualification. This suggests that most of the respondents were knowledgeable. Employment details of the respondents suggest that most of them were employed in either the public sector or private sector. There were also respondents who were self-employed.

\section{Table 1: Profile of Respondents}

\begin{tabular}{llc}
\hline \multirow{2}{*}{ Gender } & Male & $58(41.4 \%)$ \\
& Female & $82(58.6 \%)$ \\
\hline \multirow{3}{*}{ Marital status } & Single & $60(42.9 \%)$ \\
& Married & $78(55.7 \%)$ \\
& Divorcee & $02(1.4 \%)$ \\
\hline \multirow{5}{*}{ Number of family members } & 2 or less & $13(9.28 \%)$ \\
& $2-4$ & $59(42.15 \%)$ \\
& $5-6$ & $50(35.72 \%)$ \\
Residential district & 7 and above & $18(12.86 \%)$ \\
\hline \multirow{5}{*}{ Education } & Colombo & $54(38.6 \%)$ \\
& Gampaha & $33(23.5 \%)$ \\
& Kaluthara & $53(37.9 \%)$ \\
\hline & A/L pass & $46(32.9 \%)$ \\
& Diploma & $15(10.7 \%)$ \\
& Bachelor's degree & $38(27.1 \%)$ \\
Employment & Professional qualifications & $28(20.0 \%)$ \\
& Others & $13(9.3 \%)$ \\
\hline
\end{tabular}

\section{Reliability and validity}

Table 2: Reliability and validity

\begin{tabular}{|c|c|c|c|c|c|c|c|}
\hline \multirow{2}{*}{ Variable } & \multirow{2}{*}{$\begin{array}{l}\text { Cronbach's } \\
\text { Alpha }\end{array}$} & \multirow{2}{*}{$\begin{array}{l}\text { Composite } \\
\text { Reliability }\end{array}$} & \multirow{2}{*}{ AVE } & \multicolumn{4}{|c|}{ Discriminant validity } \\
\hline & & & & 1 & 2 & 3 & 4 \\
\hline $\begin{array}{l}\text { Functional repair } \\
\text { efforts }\end{array}$ & 0.717 & 0.842 & 0.641 & 0.801 & & & \\
\hline Affective repair efforts & 0.700 & 0.815 & 0.526 & -0.41 & 0.725 & & \\
\hline $\begin{array}{l}\text { Informational repair } \\
\text { efforts }\end{array}$ & 0.701 & 0.809 & 0.460 & 0.143 & 0.404 & 0.678 & \\
\hline Repurchase intention & 0.799 & 0.887 & 0.725 & 0.194 & 0.394 & 0.531 & 0.852 \\
\hline
\end{tabular}

Reliability assesses the consistency of survey items or to what extent the survey items reflect a construct. The Cronbach's Alpha coefficient measuring the reliability of the constructs are given in Table 2. All the constructs report a coefficient value of 0.7 and above. According to Nunnally and Bernstein (1994), a Cronbach's Alpha coefficient of 0.7 is an acceptable level of reliability. Fornell and Larcker (1981) suggest composite reliability (CR) of 0.6 or more and average variance extracted (AVE) greater than 0.5 meets convergent validity expectations. According to Mirzaei, Dehdari, Taghdisi, \& Zare (2019), convergent validity can be confirmed even if AVE is lesser than 0.5, but CR is above 0.6. According to Table $2 \mathrm{CR}$ is above 0.8 for all 
the variable. AVE of the informational repair efforts variable is 0.46 , and for all other variables, it is above 0.5 . Although the informational repair efforts variable has an AVE below 0.5, its CR is greater than 0.8. Fornell and Larcker (1981) suggest that the square root of each construct's AVE should be greater than its correlation with other constructs to establish discriminant validity. Table 2 depicts that the square root of each construct's AVE is greater than its correlation with other constructs. Thus, providing evidence of discriminant validity.

\section{Univariate and bivariate analysis}

Descriptive statistics and correlation coefficients between variable are presented in Table 3. The mean values range between 3.08 and 6.15 , and the standard deviation range between 0.552 and 1.095 . The highest absolute Skewness statistic is reported for informational repair efforts $(\mathrm{Sk}=-.35)$, and the highest absolute Kurtosis statistic is reported for functional repair efforts $(\mathrm{K}=$ 1.106). In sum, descriptive statistics suggest the variables have not significantly departed from a normal distribution.
According to the Pearson correlation matrix in Table 3 there is positive and significant association between functional repair efforts and repurchase intention ( $r=$ $.194, p=.022)$. Similarly, there is a positive and significant association between affective repair efforts and repurchase intention $(r=.394, p<.01)$ and informational repair efforts and repurchase intention $(r=.531, p<.01)$. The highest correlation coefficient is reported between informational repair efforts (IR) and repurchase intention (RI), and the next highest correlation coefficient is between affective repair efforts and information repair efforts ( $r=$ $.404, p<.01)$. The strength of the correlation between variables in this study can be interpreted based on Cohen's classification of correlation strength into small $(0.1<|\mathrm{r}|<0.3)$, medium $(0.3<|\mathrm{r}|$ $<0.5)$, and large $(|\mathrm{r}|>0.5)$ (1998). The highest VIF value reported is 1.232 . Since there is no high correlation between the variables and the VIF values are well below the stipulated threshold level, multicollinearity is unlikely.

Table 3: Descriptive statistics and correlation

\begin{tabular}{lcccc} 
& 1 & 2 & 3 & 4 \\
\hline Functional repair efforts & 1 & & & \\
Affective repair efforts & -0.041 & 1 & & \\
Informational repair efforts & 0.143 & $0.404^{* *}$ & 1 & \\
Repurchase intention & $0.194^{*}$ & $0.394^{* *}$ & $0.531^{* *}$ & 1 \\
\hline Mean & 3.08 & 5.58 & 5.87 & 6.15 \\
Std. Deviation & 1.095 & 0.556 & 0.552 & 1.079 \\
Skewness & 0.054 & -0.174 & -0.35 & 0.042 \\
Kurtosis & -1.106 & -0.277 & -0.107 & -0.307 \\
VIF & 1.033 & 1.209 & 1.232 & - \\
\hline
\end{tabular}

*significant at 0.05 level (2-tailed), ${ }^{* *}$ significant at 0.01 level (2-tailed).

\section{Testing of hypotheses}

Table 4: Regression results

\begin{tabular}{lccccc}
\hline & $\mathrm{B}$ & $\mathrm{SE}$ & $\mathrm{Beta}$ & $\mathrm{t}$ & $\mathrm{p}$ \\
\hline Constant & -1.569 & .943 & - & -1.663 & .099 \\
Functional repair efforts & .141 & .070 & .143 & 2.023 & .045 \\
Affective repair efforts & .450 & .149 & .232 & 3.027 & .003 \\
Informational repair efforts & .814 & .151 & .416 & 5.386 & .000 \\
\hline $\mathrm{R}^{2}(d f=139)=.34, F=23.357, p=0.00$ & & & & \\
\hline
\end{tabular}


Table 5: Relative importance

\begin{tabular}{lccccc}
\hline & B & Beta & RI (B) & $\begin{array}{c}\text { RI } \\
\text { (Beta) }\end{array}$ & Rank \\
\hline Functional repair efforts & .141 & .143 & 0.100 & 0.181 & 3 \\
Affective repair efforts & .450 & .232 & 0.320 & 0.293 & 2 \\
Informational repair efforts & .814 & .416 & 0.579 & 0.526 & 1 \\
\hline RI = Relative importance & & & & & \\
\hline
\end{tabular}

According to the regression results in Table 4, all three predictor variables have a significant and positive relationship with repurchase intention. However, the three predictor variables explain only 34 per cent of the outcome variable's total variance. Therefore, it seems there are omitted variables that may play an essential role in determining consumers' milk powder repurchase intention. Additionally, the relative importance of each variable was examined (see Table 5). Informational repair efforts is the most critical predictor variable among the three. However, it should be noted that the relative importance of the predictor variables was evaluated using the traditional approach, and it is prone to problems where the unstandardized and the standardized relative importance of variable may give a relative importance to different variables in certain circumstances.

\section{Robustness check}

Several robustness tests were performed to meet the assumptions of multivariate analysis. First, normality was assessed by examining measures of shape and computing their critical ratios (Z-score). The values of Skewness and Kurtosis are within the acceptable threshold levels (Sk $< \pm 2, \mathrm{~K}< \pm 7$ ) (Hair, Black, Babin, $\&$ Anderson, 2010). The critical ratios of Skewness and Kurtosis were computed by dividing their test statistics from the standard errors. The highest and lowest critical ratios for Skewness was -1.707 and .263 , respectively. The lowest and highest Z-score for Kurtosis was -2.717 and -.263. According to Kim (2013) for samples between 50 and 300 critical values within \pm 3.29 reflects normal distribution. Additionally, Q-Q plots (not shown) were extracted, and these scatterplots showed that the data points mainly were positioned along the diagonal line. The above evidence suggests that data distribution is within an acceptable level of normality despite slight deviations. Next, linearity between the variables was examined using scatterplots. Straight lines or trend lines in the scatterplots suggested that linearity existed between the variables. Next, the standardized values against the standardized predicted values were plotted to check for heteroscedasticity. An eyeball test was carried out using scatterplots and observed that this assumption is not violated. Finally, the Durbin-Watson coefficient (DW $=1.678)$ was calculated to test the independence of observations. According to Gujarati (2009) and Saunders, Lewis, and Thornhill (2009) DW statistics ranges between zero to four and a value closer to two reflects independence of observations or no autocorrelation. Since the DW test statistic is within this stipulated range, it was determined that independence of observation had been established.

\section{CONCLUSION}

The purpose of this paper was to examine the impact of trust repair efforts on the repurchase intention of milk powder products affected by negative publicity. Our findings revealed that trust repair efforts have a significant and positive influence on consumers repurchase intention of milk powder products affected by negative publicity. Among the three types of trust repair efforts, we found that information repair efforts had the most significant influence on consumer repurchase intention, followed by affective repair efforts and functional repair efforts.

Our findings support the notion echoed in previous studies that trust violators in this particular circumstance the milk powder producers should pay attention to strengthen 
ties with their consumers using trust repair efforts. It seems that information repair efforts is likely to have the most significant effect on repurchase intention, and the milk powder producers may consider improving their informational repair efforts further.

We make several contributions to the existing literature. Bozic (2017) state that trust repair is a nascent area of research, and our paper contributes to this field from an underexplored economic and socio-cultural context. First, this paper provides evidence on trust repair efforts in a South Asian developing economy. Second, our findings support previous empirical work examining trust repair. Third, the paper also contributes to the growing body of literature on trust theory.

Several limitations should be taken into consideration when interpreting the results presented in this paper. The main limitation of this study is the sample. As mentioned previously, data for this study was collected during the nCovid19 pandemic. Thus, collecting a random sample was affected, although the researchers made every attempt to collect data systematically. Further, the data was collected from respondents residing in the urban areas of the western province of Sri Lanka. How far the results will hold among the rural consumers of Sri Lanka is difficult to predict. Next, the scope of this study was limited to trust repair efforts and repurchase intention towards milk powder products affected by negative publicity. Hence, conclusions cannot be drawn on whether trust repair efforts affect the milk powder brands or corporate reputation. Next, there could be differences in behavioural intention and actual behaviour towards buying milk powder due to the negative publicity.

Future studies may consider undertaking similar studies with larger samples that represent a cross-section of the consumers residing in urban and rural areas of Sri Lanka. Researchers may also consider investigating the effect of trust repair efforts on milk powder brands and the company's image. Further, studies may consider including actual behaviour that reflects consumer purchases post negative publicity. This study can also be extended to cover edible oil in Sri Lanka as there have been claims of edible oil includes chemical substance beyond the permitted level for human consumption (see "CAA removes" 2021).

\section{Disclosure Statement}

The authors declare that there is no conflict of interest and are not aware of any affiliations or funding that may affect the objectivity of this study.

\section{REFERENCES}

Ahluwalia, R. \& Gurhan-Canli, Z. (2000). The effects of extensions on the family brand name: an accessibility-diagnosticity perspective. Journal of Consumer Research, 27(3), 371-381. https://doi.org/10.1086/317591

Aneez, S., \& Sirilal. R. (2014, October 5). Sri Lanka temporarily halts some Fonterra product sales after illness. Reuters. https://www.reuters.com/article/usfonterra-sri-lanka-suspendidUKKCNOHU0NP20141005, $11^{\text {th }}$ April 2021

Boeing puts cost of 737 Max crashes at $\$ 19 \mathrm{bn}$ as it slumps to annual loss. (2020, January 29). The Guardian. https://www.theguardian.com/business/2 020/jan/29/boeing-puts-cost-of-737-maxcrashes-at-19bn-as-it-slumps-to-annualloss. $17^{\text {th }}$ April 2021.

Brown, J. D. (1969). Effect of a health hazard scare on consumer demand. American Journal of Agricultural Economics. 51(3), 676-678.

Brown, S., Chandrashekaran, M., \& Tax, S. (1998). Customer evaluations of service complaint experiences: implications relationship marketing. Journal of Marketing. 62(2), 60-76.

Bozic, B. (2017). Consumer trust repair: A critical literature review. European Management Journal. 35(4), 538-547. https://doi.org/10.1016/j.emj.2017.02.007

CAA removes N-Joy coconut oil from market (2021, April 29). Daily Mirror. http://www.dailymirror.lk/breaking_news /CAA-removes-N-Joy-coconut-oil-frommarket/108-210863. 30 ${ }^{\text {th }}$ April 2021. 
Cao, T., Shi, G., \& Yin, Y. (2014). How to repair customer trust of high-risk products after negative publicity. Nankai Business Review International. 5(4), 382-393. https://doi.org/10.1108/NBRI-03-20140015.

Central Bank of Sri Lanka. (2019). Annual Report. Central Bank of Sri Lanka, Colombo, Sri Lanka.

Chen, Y. H., Wu, J. J., \& Chang, H. T. (2013). Examining the mediating effect of positive moods on trust repair in ecommerce. Internet Research, 23(3), 355371.

https://doi.org/10.1108/10662241311331 772

Cohen, J. (1998). Statistical power analysis for the behavioral sciences. $2^{\text {nd }}$ ed. LEA.

Companies say imported milk powder safe, contrary to GMOA claims. (2020, January 23). Daily FT. http://www.ft.lk/frontpage/Companies-say-imported-milkpowder-safe-contrary-to-GMOAclaims/44-694219. 10 $0^{\text {th }}$ April 2021

Dawar, N., \& Pillutla, M. M. (2000). Impact of product-harm crises on brand equity: the moderating role of consumer expectations. Journal of Marketing Research. 37(2), 215-226. doi:10.1509/jmkr.37.2.215.18729

Dissanayake, M. (2019, October 13). CAA puts imported milk powder In 'High Risk' category. Ceylon Today. https://archive.ceylontoday.lk/printmore/42563 10 $0^{\text {th }}$ April 2021

Eagly, A. H., \& Chaiken, S. (1993). The psychology of attitudes. Harcourt Brace Jovanovich College Publishers.

Fornell, C. \& Larcker, D. (1981). Evaluating structural equation models with unobservable variables and measurement error. Journal of Marketing Research. 18(1), 39-50. doi:10.2307/3151312

Government Medical Officers' Association (2019, April 03). GMOA Official Milk Powder [Video]. YouTube. https://www.youtube.com/watch?v=kEed fxv9dgQ, 10 $0^{\text {th }}$ April 2021
Gujarati, D. (2011). Econometrics by Example. Palgrave-McMillan. Gunatilleke, N. (2020, 26 January). Imported milk powder harmful to health-GMOA. Sunday Observer.

http://www.sundayobserver.lk/2020/01/2 6/news/imported-milk-powder-harmfulhealth-gmoa?page =2. 01 ${ }^{\text {st }}$ May, 2021.

Hair, J., Black, W. C., Babin, B. J. \& Anderson, R. E. (2010) Multivariate Data Analysis. 7th ed. Pearson Educational International.

Harmful chemical found in four milk powder brands: Report (2013, Jul 26). Daily Mirror.

http://www.dailymirror.lk/32952/dcdfound-in-four-milk-powder-brandsreport. $15^{\text {th }}$ June 2020.

Hellier, P. K., Geursen, G. M., Carr, R. A., \& Rickard, J. A. (2003). Customer repurchase intention. European Journal of Marketing. $\quad 37(11 / 12), \quad$ 1762-1800. https://doi.org/10.1108/03090560310495 456.

Henthorne, H. B. \& Henthorne, T. L. (1994). The Tarnished Image: Anticipating and Minimizing the Impact of Negative Publicity in Health Services Organizations. Journal of Consumer Marketing, $11 \quad$ (3), pp. 44-54. https://doi.org/10.1108/07363769410065 463

Ibrahim, M. N. M., Staal, S. J., Daniel, S. L. A. \& Thorpe, W. (1999). Appraisal of the Sri Lanka Dairy Sector. Vol 1. University of Peradeniya, International Livestock Research Institute, \& Ministry of Livestock Development and Estate Infrastructure.

Isaeva, N., Gruenewald, K., \& Saunders, M. N. K. (2020). Trust theory and customer services research: theoretical review and synthesis. The Service Industries Journal. 40(15-16), 1031-1063. doi:10.1080/02642069.2020.1779225

Kim H. Y. (2013). Statistical notes for clinical researchers: assessing normal distribution (2) using skewness and kurtosis. Restorative Dentistry \& Endodontics, 
38(1),

$52-54$.

https://doi.org/10.5395/rde.2013.38.1.52

Kim, P. H., Ferrin, D. L., Cooper, C. D., \& Dirks, K. T. (2004). Removing the shadow of suspicion: the effects of apology versus denial for repairing competence- versus integrity-based trust violations. Journal of Applied Psychology. 89(1), 104-118. https://doi.org/10.1037/00219010.89.1.104.

Kottasova, I. (2015, November 13). Volkswagen sales plunge on emissions scandal.

CNN. https://money.cnn.com/2015/11/13/news/ companies/volkswagen-sales-emissionscandal/index.html. 16 ${ }^{\text {th }}$ April 2021.

Laufer, D., Gillespie, K., McBride, B. \& Gonzalez, S. (2005). The role of severity in consumer attributions of blame: defensive attributions in product-harm crises in Mexico. Journal of International Consumer Marketing. 17(2/3), 33-50.

Lewicki, R. J., \& Brinsfield, C. (2017). Trust repair. Annual Review of Organizational Psychology and Organizational Behavior, 4(1), 287-313. doi:10.1146/annurevorgpsych-032516-113147.

Lugoda, U. (2020, November 22). Sri Lanka's milk import problem. The Morning. https://www.themorning.lk/sri-lankasmilk-import-problem/ $11^{\text {th }}$ April 2021

Mirzaei, N., Dehdari, T., Taghdisi, M. H., \& Zare, N. (2019). Development of an instrument based on the theory of planned behavior variables to measure factors influencing Iranian adults' intention to quit waterpipe tobacco smoking. Psychology Research and Behavior Management, 12, 901-912.

https://doi.org/10.2147/PRBM.S196417

Mitroff, I. I., Shrivastava, P., \& Udwadia, F. E. (1987). Effective Crisis Management. The Academy of Management Executive, 1987-1989, 1(4), 283-292.

Nunnally, J. C., \& Bernstein, I. C. (1994). Psychometric theory (3rd ed.). New York: McGraw-Hill.
Saunders, M., Lewis, P., \& Thornhill, A. (2009). Research Methods for Business Students. $5^{\text {th }}$ ed. Pearson Inc.

Schweitzer, M. E., Hershey, J. C. and Bradlow, E. T. (2006), "Promises and lies: restoring violated trust", Organizational Behavior and Human Decision Processes, Vol. 101 No. 1, pp. 1-19.

Siriwardana, A. and Perera, Y. (2019, February 09). Harmful substances in imported milk powder - Buddhika sticks to what he said. Daily Mirror. http://www.dailymirror.lk/BreakingNews/Harmful-substances-in-importedmilk-powder-Buddhika-sticks-to-whathe-said/108-162135. 10 ${ }^{\text {th }}$ April 2021.

Smith, A. K., Bolton, R. N., \& Wagner, J. (1999). A model of customer satisfaction with service encounters involving failure and recovery. Journal of Marketing Research, 36(3), 356-372. https://doi.org/10.1177/00222437990360 0305

Smith, M. E., van Ravenswaay, E. O., \& Thompson, S. R. (1988). Sales loss determination in food contamination incidents: an application to milk bans in Hawaii. American Journal of Agricultural Economics, 70(3), 513-520. doi:10.2307/1241489

Sullivan, Y. W., \& Kim, D. J. (2018). Assessing the effects of consumers' product evaluations and trust on repurchase intention in e-commerce environments. International Journal of Information Management, 39(July 2017), 199-219.

https://doi.org/10.1016/j.ijinfomgt.2017.1 2.008

Swartz, D. G., Strand, J. E. (1981). Avoidance costs associated with imperfect information: the case of Kepone. Land Economics, 57, 139-50.

Turnbull, P.W., Leek, S. \& Ying, G. (2000). Customer confusion: the mobile phone market. Journal of Marketing Management, 16(1/3), 143-163.

Xie, Y., \& Peng, S. (2009). How to repair customer trust after negative publicity: the 
roles of competence, integrity, benevolence, and forgiveness. Psychology \& Marketing, 30, 572-589. https://doi.org/10.1002/mar

Vidanaarachchi, J. K., Chathirika, H. M. M., Dias, H. M., Korale Gedara, P. M., Silva, G. L. L. P., Perera, E. R. F, \& Perera, A. N. F. (2019). Dairy Industry in Sri Lanka: Current Status and Way Forward for a Sustainable Industry. Sri Lanka Association of Animal Production.

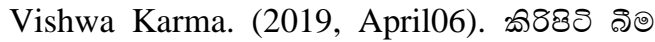

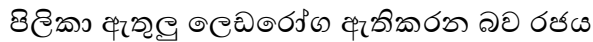

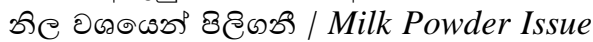
In Sri Lanka [Video]. YouTube. https://www.youtube.com/watch?v=o9_n hm_2_ow, 01 ${ }^{\text {st }}$ October 2020.

Vyravene, R., \& Rabbanee, F. K. (2016). Corporate negative publicity - the role of cause related marketing. Australasian Marketing Journal, 24(4), 322-330. doi:10.1016/j.ausmj.2016.11.006

Youn, H., Lim, B. I., \& Jin, H. J. (2012). Differential effects of negative publicity on beef consumption according to household characteristics in South Korea. Health Policy, 106(2), 138-148. doi:https://doi.org/10.1016/j.healthpol.20 12.03.005

Yu, M., Liu, F., Lee, J., \& Soutar, G. (2018). The influence of negative publicity on brand equity: attribution, image, attitude and purchase intention. Journal of Product and Brand Management, 27(4), 440-451. https://doi.org/10.1108/JPBM01-2017-1396 


\section{Annexure}

Functional repair efforts - (Cao, Shi \& Yin (2014), Chen, Wu \& Chan (2013)

1. Consumers have received concrete compensation from the company

2. The company has made an effort to respond to the negative publicity

3.The company has offered economic compensation for any losses related to the negative publicity

Affective repair efforts - Cao, Shi \& Yin (2014), Chen, Wu \& Chan (2013)

1. The company has made an obvious apology to the victims and the public

2. Customers have received spiritual compensation

3. The company has taken account into account consumers' emotions in responding to the negative publicity

4. The company has held a forum to make an apology, helping me to feel the company's sincerity

Informational repair efforts - Cao, Shi \& Yin (2014), Chen, Wu \& Chan (2013)

1. Customers were clearly informed about the company's response to the negative publicity

2. The company has published all the necessary information about its response to the negative publicity

3. The company has provided evidence to prove the current quality of its milk powder products

4. The company has provided evidence to prove its milk powder products are now up to international quality standards

5. The company has provided evidence to prove its other products to be qualified

Repurchase intention Cao, Shi \& Yin (2014), Chen, Wu \& Chan (2013)

1. I think I will purchase Sri Lankan dairy products in the future

2. I think it will be possible to purchase Sri Lankan dairy products in the future

3. I hope to purchase Sri Lankan dairy products in the future 